\title{
A conceptual framework for defense logistics
}

\section{Um arcabouço conceitual para logística de defesa}

GESTÃO PRODỰC̄OO

ISSN 0104-530X (Print) ISSN 1806-9649 (Online)

How to cite: Brick, E. S. (2019). A conceptual framework for defense logistics. Gestão \& Produção, 26(4), e4062. https://doi.org/10.1590/0104-530X4062-19

\begin{abstract}
Defense logistics (DL) is an important and yet unexplored knowledge area of Production Engineering. Therefore, the purpose of this paper is to establish the DL problem domain. The focus is on industrial, technological, institutional, organizational and, specially, strategic management aspects applied to logistics in the defense sector. It also proposes a conceptual framework identifying DL objectives, functional areas and interfaces with the environment. The framework defines the Defense Logistics Base (DLB) as a system meant to create and sustain military capability, but also involved with the development of industrial capability, related to high and medium-high technologies, applied to high value products, with dual use. Furthermore, it suggests a research agenda for future work on strategic management related to DL.
\end{abstract}

Keywords: Defense logistics; Industry policy; Innovation management; Organizational theory; Product development management; Strategic management.

Resumo: Logística de defesa (LD) é uma importante e ainda inexplorada área de conhecimento da Engenharia de Produção. Assim, este artigo tem como propósito estabelecer o domínio de problema de LD. O foco recai sobre aspectos industriais, tecnológicos, institucionais, organizacionais e, principalmente, de gestão estratégica, aplicáveis à logística no setor de defesa. Também se propõe a desenvolver um arcabouço conceitual identificando objetivos da LD, áreas funcionais, componentes estruturais e interfaces com o ambiente externo. $O$ arcabouço define Base Logística de Defesa (BLD) como um sistema destinado a criar e sustentar capacidade militar, mas também envolvido em desenvolver capacidades industriais, associadas a alta e média alta tecnologias, para produtos de elevado valor agregado, com uso dual. Ao final propõe uma agenda para pesquisa futura sobre gestão estratégica em LD.

Palavras-chave: Logística de defesa; Politica industrial; Gestão da inovação; Teoria das organizações; Gestão do desenvolvimento de produtos; Gestão estratégica.

\section{Introduction}

This paper covers a problem domain of great relevance for Production Engineering, although yet scarcely studied. It deals with the set of activities meant to create and sustain military capabilities, which are essential to safeguard States' independence and sovereignty, as well their advantageous insertion in the international system. Ultimately, these are the capabilities that guarantee States' survival as autonomous entities and capable to decide, without external interferences, about the destiny of theirs populations. Consequently, the subject defense is very important and strategic for any country.

This problem domain belongs to the knowledge area known as defense logistics (DL). Peppers (1988 apud Gropman, 1997, p. xiii) gave a concise definition of (defense) logistics: "Logistics is a system established

to create and sustain military capability". One of the objectives of this paper is exactly to establish the problem domain and to propose a conceptual framework for DL.

Military capabilities' planning, development, implementing and sustaining are very complex activities. They require adequate institutions and a great number of professionals both military and civilian, employed by the State, with specific management skills. These activities consume significant portions of the resources available in a country and demand long deadlines to be met. Paradoxically, they have received very little attention from mainstream scholar journals. Yoho et al. (2013, p. 92), in the introductory paper published in the special issue on DL of the International Journal of Physical Distribution \& Logistics Management

\footnotetext{
${ }^{1}$ Universidade Federal Fluminense - UFF, Rua Passo da Pátria, 156, sala 440, Bloco E, CEP 24210-253, Niterói, RJ, Brasil, e-mail: brick@producao.uff.br
}

Received June 6, 2017 - Accepted Mar. 7, 2018

Financial support: None. 
suggest " $[\ldots]$ the relative absence of literature in this complex but absorbing field represents an 'open goal' for researchers!" The findings of Defee et al. (2010) about logistics and supply chain management (SCM) research, corroborates Yoho et al.appraisal. In the 683 papers surveyed, only one included "defense" or "defence" in the title.

Additionally, the few papers published in journals about the subject of defense confirm that the topic is interdisciplinary, as indicated by the references cited by Yoho et al. (2013), Brick (2016) and in this paper. Some of these use approaches of the knowledge areas of logistics, management, decision sciences, public administration, history, medicine, physical distribution, operations research, strategic studies, economy, political science, production engineering, political economy and military sciences.

In this paper the focus is on defense strategic management. That is, it covers the activities that involves decisions, by high-ranking government officials, about resources allocations to defense and the way to manage them. The strategic management area underwent great development following the initial work of Penrose (1959) and the resource-based theory of the organizations. Nevertheless, this theory shows organizations' static views and not theirs transformations to adapt to an environment in constant mutation. The answer to this problem appears in Teece et al. (1997) with the dynamic capabilities theory. This theory targets the high technology business environment, highly dynamic and competitive. The defense sector faces an environment yet much more aggressive and competitive, which requires a broad spectrum of high technologies and where failure represents loss of sovereignty. Therefore, this is a much more complex environment and requires, with greater reasons, conceptual frameworks and theories as the ones already developed for the civilian sector. Particularly, there is a lack of conceptual frameworks useful to map, relate and organize research in this area.

A framework, like a model, abstracts from reality.
It endeavors to identify classes of relevant variables
and their interrelationships. A framework is less
rigorous than a model as it is sometimes agnostic
about the particular form of theoretical relationships
that may exist (Teece, 2009, p. 5).

The meaning of the word logistics originated in the military sector but changed somewhat when adopted in the business environment and has evolved continuously since then. Brick (2016) made a bibliographic research about the evolution of the various meanings attributed to the term, as well as others related, such as supply chain, have had over time in both environments.

Stanley Falk, in the introduction to the third edition of Thorpe's book, defines (defense) logistics in two levels: one mainly operational, with a view towards combat capability sustainment and the other, with a broader view, dealing with capability creation (great logistics) (Thorpe, 1996, p. xi):

\begin{abstract}
Logistics is essentially moving, supplying, and maintaining military forces. It is basic to the ability of armies, fleets, and air forces to operate--indeed, to exist. It involves men and materiel, transportation, quarters and depots, communications, evacuation and hospitalization, personnel replacement, service, and administration. In its broader sense, it has been called the economics of warfare, including industrial mobilization, research and development, funding, procurement, recruitment and training, testing, and, in effect, practically everything related to military activities besides strategy and tactics.
\end{abstract}

Yoho et al. (2013) describe current research about DL and propose an agenda for future work, which has been explored, discussed and enlarged by Brick (2016). This agenda covers a broad spectrum of specific problems but falls short of addressing the more basic conceptual and theoretical aspects, with a view on DL strategic management. One of the objectives of this paper is to suggest an alternative agenda to cover this topic. That is, these agenda complement each other and anyone interested in DL will find broad research spectrum in these three papers.

For Gammelgaard (2004, p. 479)

[...] logistics research can be divided into two schools based on the underlying methodological approach. The schools are the analytical school, building on positivism, and the systems school, building on systems theory.

This paper follows the latter.

The paper has the following structure. This introduction presents the context and the objectives. Section 2 presents a bibliographic review, with a narrow filter for texts that include conceptual elements and constructs applicable to this problem domain. Section 3 proposes a conceptual framework for DL. Section 4 proposes an agenda for future research about important topics related to DL strategic management and, lastly, section 5 presents the conclusions.

\section{Bibliographic review about concepts and frameworks applicable to defense strategic management}

As mentioned in the Introduction, Brick (2016) describes the temporal evolution of the meanings of the word logistics in the defense and business environments. He alerts that to understand the meaning of logistics in both environments it is necessary to consider that the market economy nature is very distinct from the defense one in at least two fundamental aspects. 
First:

DL is a State's instrument for the safeguard of its auto determination, security and capability to actuate in the international system. In other words, defense logistics, as well as the Armed Forces, require adequate defense budgets and public institutions with the responsibility for its management and sustaining. It not only can, indeed it must, be treated as a system with centralized management under direct State responsibility. In the civilian business environment, extremely diversified, there is not a similar central role for the State and, at the end, each firm is responsible for its own logistics (Brick, 2016, p. 311) (Translated from Portuguese by the author).

\section{Secondly:}

Although considerations about efficiency in the allocation of resources are paramount in economic studies, when dealing with defense, effectiveness is the main factor to be considered, since power among States is a relative and not an absolute concept (Brick, 2016, p. 312) (Translated from Portuguese by the author).

Therefore, there are fundamental differences between the contexts in which defense and business logistics operate. For DL, the central role of the State warrants to conclude that it has the responsibility to create and sustain a system capable to develop, or at least control directly, all logistics activities.

In the defense sector, although one encounters definitions about the meaning of logistics, as in Eccles (1965), Peppers (1988), Gropman (1997) and United States (2011), there are not many texts covering conceptual frameworks or theoretical constructs. Ellram (1993), New \& Payne (1995), Olavarrieta \& Ellinger (1997) and Waeyenbergh \& Pintelon (2002, 2009) discussed research frameworks related to DL. Nevertheless, none of them addressed DL as a whole, with a vision towards defense strategic management. Among the ones that used this approach, we found Thorpe (1996), Tellis et al. (2000), Markowski et al. (2010), Brick $(2011,2014,2016)$ and Brick et al. (2017).

The first author to identify the central role reserved to the State, and the necessity of a system to take care of DL, was Thorpe (1996) in his work originally published in 1917 and republished seven decades later by the National Defense University of the USA. As it so happens with ideas ahead of their time, Thorpe's conception remained asleep for a long time and was understood and accepted only after the Second World War. Today, a great number of nations accept his ideas and they constitute the first and most important pillar of a conceptual framework for DL.

Brick (2011) coined the term Defense Logistics Base (DLB) to represent the system responsible for DL activities. He defined these two entities as follows:
Defense Logistics (DL) refers to the provision of means to compose the Armed Forces (AF) and to sustain their operations in any situation they might be employed.

Defense Logistics Base (DLB) is an aggregate of human, material and technological capabilities, needed do develop and sustain the national power military component, but also deeply involved with the development of the industrial capability and competitiveness of the country as a whole.

Observing these two definitions, it's possible to verify that the DLB has a much broader objective than solely executing DL activities. It would also have an important role in the development of a country's industrial capability and competitiveness as a whole, and not only its military capability. The broadening of the DLB scope is not arbitrary and stems from the fact that this is the current practice of a number of countries with high industrial development. Apparently they consider being impossible to separate military capabilities from others that provide the foundations of national power, defined by Tellis et al. (2000, p. 44) as "[...] a country's capacity to pursue strategic goals through purposeful action". A strong evidence is the high percentage of total investments in research and development (R\&D) under direct responsibility of Ministries of Defense (up to $70 \%$ in the case of the USA) of the governments of eight industrialized countries members of the Organization for Economic Co-operation and Development (OECD) (Mowery, 2012).

Brick (2014, p. 15-16) offered the following justifications for extending the DLB scope beyond defense:

Industrial and science, technology and innovation (ST\&I) defense policies offer great advantages to any country because they:

a) Do not burden the economy at large since all costs are encapsulated in the defense budget;

b) Are immune from commercial retaliations such as those provided for in the World trade Organization (WTO);

c) Operate at the threshold of technological development, providing innovations almost always possessing dual use; and

d) Develop industrial capabilities for high aggregated value products that may also generate goods for civilian applications (in Brazil, Embraer is an emblematic example of this advantage) (Translated from Portuguese by the author)

The expressions military capability and national power military component appear in Peppers (1988) 
and Brick (2011), respectively, in theirs definitions of DL. These terminologies are synonyms but they do not account for the comprehensiveness of the concepts represented. For this reason, these will be more precisely explained below.

For Tellis et al. (2000), military capability depends on two factors: strategic resources and a conversion capability of these resources into combat proficiency. The strategic resources have three distinct components:

a) The defense budget;

b) Military personnel, facilities infrastructure and warfighting inventory (the Armed Forces);

c) Logistic support infrastructure (to provide warfighting inventory availability and to supply the Armed Forces with food, drugs, ammunition and energy), combat $R \& D$ and test and evaluation (T\&E) institutions and the defense industrial base (a system responsible for DL).

As seen above, for Tellis et al. (2000), military capability is a broad concept that includes not only combat capabilities, but also industrial and technological as well, all of them considered essential to achieve combat proficiency.

Nowadays, combat (or operational) capability is understood as a combination of trained personnel and support that allows the Armed Forces to execute the tasks allocated to them. It takes in consideration, among other factors, doctrine, organization, training, materiel (equipment and consumables), leadership, personnel, facilities, information, interoperability and logistics (of operation), synthesized in the acronym DOTMLPIIIL (Brick et al., 2017).

Brick (2014) used the approach by Tellis et al. (2000) to create the concept of Defense Instruments: the $\mathrm{AF}$, represented by item $\mathrm{b}$ ) of the strategic resources; and the DLB, which encompasses the resources listed in item c). Nevertheless, the DLB concept presented by Brick (2011), as already mentioned, is more comprehensive than item c) of Tellis et al. (2000) strategic resources may suggest, because it includes the development and sustaining of industrial capability in high and medium-high technologies in general, with application in wider sectors. In fact, the DLB is the closest link of the tight relation between defense and development, recognized by the Brazilian National Defense Strategy (Brasil, 2012b).

Markowski et al. (2010) approached the DL problem under two views: defense acquisition and industrial policies. The authors did not use the term "logistics", although the main objective of the text - defense acquisition - is one of defense logistics main activities. Applied economy was the main approach, with contributions from law and management sciences, and practices from acquisition and industrial policies. The main questions related to acquisition policies they tried to answer are central in defense logistics:

a) Suitability of the adoption of local contents industrial policies;

b) Choice between State controlled production, or reliance on acquisition from external sources;

c) How to select suppliers? Market competition, or preferred suppliers?

d) What contract types to use?

e) How to manage the supply process and relations with suppliers?

Industrial policies cover all actions taken by governments to directly influence decisions by productive agents operating inside State borders. Given the strategic character of the defense instruments for the sovereignty of any nation, defense industrial policies may be considered essential, since the defense products industry is the core component of the DLB. Nevertheless, this importance varies among countries, due to different perceptions and, also, individual capabilities to sustain an autochthone defense industry. Perhaps for this motive, Markowski et al. (2010) see industrial policy as a sub set of acquisition policy. The defense industry would become relevant only if a government decides to base its defense logistics on a national production capability. Therefore, the authors assume that it is possible to build a defense capability with a strong dependence on foreign suppliers for the means required to create military combat capability. Indeed, this model adheres to historical facts. Many countries, Brazil included, depended in the past, and still depend today, almost totally on others to supply theirs AF with the means they need. Nevertheless, it is doubtful that this alternative applies universally to all States, regardless of size and interests to protect. The authors, themselves, affirm that the model applies to small countries with advanced industrial economies and not to countries with high effective power, such as the United States, United Kingdom and France, or countries with high potential power, such as China, Brazil and India, for example. Additionally, there exists a new paradigm that may jeopardize a great dependence on foreign suppliers for the AF. Technological development acceleration turn defense products obsolete in shorter periods of time. This phenomenon, together with technology control policies practiced by countries who develop critical technologies creates a new reality for defense planning. Brick (2014) covered this subject and concluded that the consequence of this new reality is to increase DLB relative importance as a defense 
instrument. Indeed, in the present post-industrial age, the DLB is a defense instrument as important as the $\mathrm{AF}$ themselves. Without this base, nowadays it seems impossible to achieve a defense posture capable to guaranteeing a minimum degree of autonomy and free will to national States. This happens because, if it is possible to quickly strengthen a combat capability, by adding men and materiel to existing military units, the same does not occur when the objects are industrial and technological capabilities. The latter demand decades to be created. That is, Thorpe's (1996) ideas still hold true in spite of the great technological evolution in the art of war for the last one hundred years since they were conceived.

In summary, Markowski et al. (2010) framework adopts two main perspectives: what to furnish, or the products demanded by the $\mathrm{AF}$, and the players and decision makers, or who is involved in the process.

The first perspective is equivalent to a defense value chain, or supply chain.

The final product is a defense system, consisting of the integration of specialized combat capabilities (and not simply the sum, what also requires high intelligence, reconnaissance and command and control capabilities), proper to a set of likely scenarios, expressing contingencies that require the use of military forces, in the medium term (normally 10 to 20 years).

States should act rationally in order to be able to plan their defense. The sought capabilities usually target two main objectives: to provide a credible deterrence capability and the possibility of an actual employment of military force in some specific situations, foreseen in the prioritized scenarios.

An important aspect of the defense sector, that differentiates it from the civil one, is that many of the defense final products are contingent, in the sense that they are effectively delivered only if the foreseen military contingencies do occur. That is, their value can only be assessed ex post. Likewise, when dealing with deterrence, it is impossible to determine if the absence of external aggression is due to the developed military capabilities or other factors (Markowski et al., 2010).

The second perspective considers the system responsible for the functioning of the defense value chain. Markowski et al. (2010) define the following entities that compose this system:

a) One National Defense Organization (Ministry or Department), responsible for the production of the national defense and the creation of the input demand for defense; b) One Defense Acquisition Agency, responsible for a significant plot of the defense logistics; and

c) Defense products suppliers, responsible for the supply of the demanded defense inputs.

\section{A conceptual framework for defense logistics}

The previous section presented some essential elements for the construction of a conceptual framework about DL, derived from the works of Thorpe (1996), Tellis et al. (2000), Markowski et al. (2010), Brick $(2011,2014,2016)$ and Brick et al. (2017). In summary:

a) The need of permanent State institutions, operated by professionals with a public career, either military or civilian, responsible for the production of the national defense;

b) The concept of Defense Logistics, as an activity meant to create and sustain military capability;

c) The amplified concept of Military Capability, which is the final objective of defense logistics and measured only by effective combat proficiency. It has three dimensions (combat, industrial-technological and innovation) and is composed by the strategic resources and by a conversion capability to transform these resources into combat proficiency. That is, the strategic resources constitute a necessary, but not a sufficient condition. Conversion capability may be thought as an intangible asset that depends on a complex interaction among various factors, such as population culture, shared values and national institutions in a broader sense, in addition to specific characteristics of the military institutions;

d) The concept of Combat (or Operational) Capability, resulting from the integration of factors synthetized in the acronym DOTMLPIIIL: doctrine, organization, training, materiel (equipment and consumables), leadership, personnel, facilities, information, interoperability and logistics (of operation);

e) The central role played by the State in defense and its responsibility to create and sustain a system capable of executing defense logistics activities; 
f) The concept of Strategic Resources, composed by the defense budget and by the Defense Instruments;

g) The concept of Defense Instruments, composed by the Armed Forces, which are responsible for the creation, development, maintenance and training of operational combat units, that materialize combat capabilities; and by the Defense Logistics Base, that provides the means to create and sustain military capability in the broader sense;

h) The central role played by the activity that defines military capabilities (combat, industrialtechnological and innovation) suitable to the foreseen scenarios, considered relevant for the country defense. This activity requires extensive involvement of members of the political establishment, as the first step for the defense logistics process. The late functions as a defense chain value, or supply chain targeted to achieve those capabilities.

Based in these elements, a conceptual framework, focused on the strategic management of DL was conceived. The framework starts with an amplified concept of defense logistics, in order to encompass the broader meaning of military capability by Tellis et al. (2000), and the related concept of Defense Logistics Base.

Defense Logistics is a system established to create and sustain the Defense Instruments: the Armed Forces and the Defense Logistics Base.

Defense Logistics Base is an aggregate of human, material and technological capabilities, needed do develop and sustain the Defense Instruments, but also deeply involved with the development of the industrial capability and competitiveness of the country in leading technological sectors.

These two concepts are adherent with the broader perception by Tellis et al. (2000) about national power and military capability. The authors emphasize that these depend on the development of production modes that allow the nation to dominate innovation cycles and, as a result, amplify its hegemonic potential in the global economy, by means of the creation of sophisticated military forces.

These definitions expand the concept of defense logistics to include, in addition to the two types found in the literature (Supplier, or producer, logistics; and consumer, or operations, logistics.), a third type that, although largely practiced by industrialized countries, so far to our knowledge has not been formalized in the literature as a new category (DLB Logistics): a) Provisioning of the Armed Forces Logistics - PAFL (supplier or producer logistics, big logistics - "Big L", or defense economy): for the creation of operational military capability, by providing the Armed Forces with the needed means;

b) Operations Logistics - OL (operations logistics, consumer logistics or small logistics - "Small l"): to support military operations, by providing services and furnishing, when and where necessary, the supplies produced by PAFL. Nowadays these activities are shared, in different degrees, by the AF and by the DLB, depending on each country's institutions;

c) Defense Logistics Base Logistics - DLBL: to develop and sustain industrial and technological capabilities, providing the DLB with the necessary means. The fact that nowadays the DLB is a defense instrument as important as the AF justifies the need of a specialized logistics system with the mission to create and sustain it.

Figure 1 summarizes DL partition in three types.

It is important to notice that the three categories are interdependent and contribute to the attainment of each other's objectives. For example, weapons systems acquisition, a supplier activity, contributes directly to the sustainment of the DLB, one of the goals of DLB Logistics. As for PAFL effect on operations logistics, the development and acquisition of new weapons systems allow the exploitation of the concept of Integrated Logistics Support (ILS) at its best, by creating opportunities to optimize maintenance activities. Conversely, the opportunity to participate directly in maintenance activities of the systems it develops and furnishes, helps to sustain the DLB.

As mentioned in the Introduction, the approach used in this paper is derived from system theory. Considering the DLB as a system with specific

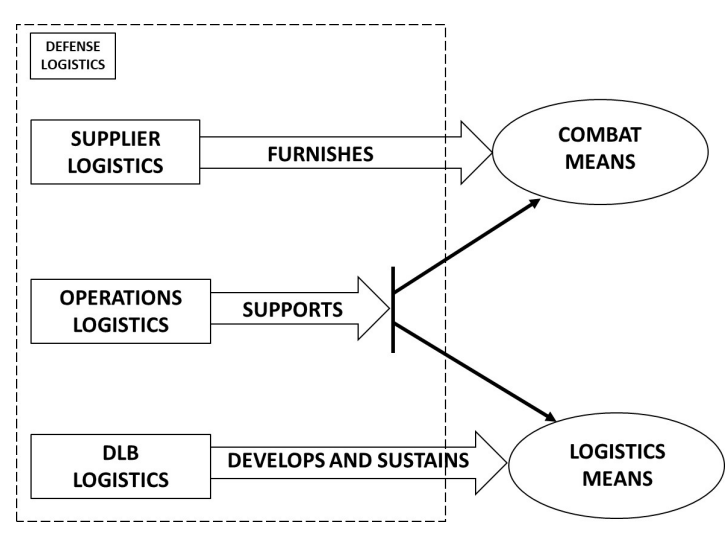

Figure 1. Defense Logistics (DL) taxonomy. 
goals (a teleological, or purposeful, system), one may analyze it using the framework proposed by Sutherland (1975). The author suggests examining a system by determining the properties it exhibits in three dimensions:

a) Structure: the nature of its components, how they are distributed and the prevailing relationships among them;

b) Dynamics: processes or behavior (how the system work); and

c) Interfaces: its relationships with the outside world or external environment (any system is defined within certain boundaries that separate it from the external environment or ecology).

Systems structure and dynamics are "plastic", in the sense that they may be altered at will, as long as the effectiveness or efficiency may be improved. The environment can also change with time, although normally in an uncontrolled way. The system objective, nevertheless, cannot change, since it is what ultimately defines the system. This characteristic warrants the partition of DLB into the three subsystems, each one with a very distinct objective: Provisioning of the Armed Forces Logistics Subsystem (PAFLS), Operations Logistics Subsystem (OLS) and Defense Logistics Base Logistics Subsystem (DLBLS).

What follows is the development of a new conception for the structure, dynamics and interfaces of the three above mentioned subsystems, based on a broad analysis of the realities of different countries.

Some additional considerations about the methodology used are desirable. A relevant part of the knowledge used in this analysis is tacit and derived from the author personal experience in the defense sector. As affirmed by Polanyi (2009), tacit knowledge is paramount for science development and cannot be codified and represented in published texts, scholarly or otherwise, that may be cited:

I am looking at Gestalt... as the outcome of an active shaping of experience performed in the pursuit of knowledge. This shaping or integrating I hold to be the great and indispensable tacit power by which all knowledge is discovered and, once discovered, is held to be true (Polanyi, 2009, p. 6).

For Polanyi (2009), tacit knowledge is shown to account for a valid knowledge of a problem, for the scientist's capacity to pursue it, guided by his sense of approaching his solutions, and for a valid anticipation of the yet indeterminate implications of the discovery arrived at in the end. Still according to Polanyi (2009), tacit knowledge and Gestalt explain why the human mind is capable of integrating, in a whole, particular aspects of a reality that cannot describe precisely.
Therefore, this approach is recommended when the research goal is to obtain a holistic view about a given problem domain, particularly when there is a literature shortage, as happens with defense logistics.

Complementarily, we made an extensive bibliographic review about the defense structure of different nations, with a focus on defense logistics. The following references were very useful for the framework construction: Brazil (Brasil, 2012a, b; Masson et al., 2015; Melo, 2015), United States (Heidenkamp et al., 2013; United States, 2017; Kausal \& Markowski, 2000), Germany (Heidenkamp et al., 2013), Australia (Markowski et al., 2010; Australia, 2014; Kausal \& Markowski, 2000), France (Giovachini, 2000; Behera, 2016), Sweden (Brick, 2017; Sweden, 2014; Markowski et al., 2010; Ekstrom et al., 2015), India (Behera \& Kaushal, 2013; Behera, 2016), United Kingdom (Great Britain, 2014; Ekstrom et al., 2015), Singapore (Kausal \& Markowski, 2000; Markowski et al., 2010), Netherland, Israel and Canada (Markowski et al., 2010) and Japan and South Korea (Kausal \& Markowski, 2000). Behera \& Kaushal (2013) presented best practices for defense acquisition in a variety of countries, including some of the above mentioned. These references allowed gathering useful elements used in this work and also, but and not less important, verifying the adherence of the established concepts to reality.

Whether one considers something as being part of the structure or the external environment is, to a certain extent, a question of choice. A reasonable criterion is to consider as part of the structure everything that is eligible to change by whom is involved with the problem.

With respect to the DLB structure, one can observe significant differences in the way countries organize these components. Although the framework does not propose universal solutions to organize logistics defense system structures, it identifies components and functions usually found and indicates the need to manage DL in a very different way the Armed Forces do with respect to military combat operations.

As for the system dynamics, there is a mandatory process to define a strategy and to plan national power development and sustainment. Taylor (2013), O'Hanlon (2009), The Technical Cooperation Program (TTCP, 2006), and Davies (2002) treat these questions using a broad approach. More specifically, defense planning requires a process that is common to operations and logistics and works as the interface among the AF, the DLB, the government as a whole and the legislative branch. The result is a defense policy, establishing the main defense objectives, the required military capabilities (combat, industrial and technological) and a defense strategy compatible with these objectives and capabilities. All these elements depend on reliable estimates about the available 
and needed resources and the international scenario anticipated for the contemplated planning horizon. A medium-term and more detailed defense planning is then developed, grounded on the policy, strategy and affordable defense budgets.

The defense budget is the main financial source available, since external aid, even if in the form of donations in coalition's arrangements, or financing, normally attached to acquisitions from the financing country, are also usual, but not trustful when it comes to long term planning. It follows that the planning should be compatible with defense budgets and these should be multiannual. The main strategic decisions relate to tradeoffs among the objectives related to the desired combat capabilities, represented by the AF sizes (personnel, weapons and facilities) and to the industrial and technological capabilities, represented by the DLB configuration (defense industries, schools and $C \& T$ institutions, human resources, etc.) for the three DLB subsystems during peacetime, with the implications they have on the budget.

War deserves particular treatment, since one cannot anticipate the bigger efforts required in these situations.

It is possible to decompose each of the DLB subsystems into functional areas (FA) that are universal. The allocation of functional areas also involves some subjectivity and arbitrariness, because some might belong to more than one DLB subsystem. To avoid ambiguities, the adopted criterion was that the function should contribute directly to the attainment of the main subsystem's objective.

That said, follows a description of the three DLB subsystems in terms of structure, functional areas, dynamics and interfaces.

\subsection{Provisioning of the Armed Forces Logistics Subsystem (PAFLS)}

The objective of the SPAFL is to provide all types of means needed by the Armed Forces: personnel, weapons, munitions, facilities, energy, medicine, food, services, etc. To achieve this goal it develops producer, supplier, defense economy or "Big L" logistics activities.

National resources and the country's economy as a whole provide these means. The DLB provides defense-dedicated resources and the interface between the Armed Forces and broader national resources. The main SPAFL structural components are:

a) Defense industry and part of its supply chain, both public and private, considered strategic and subject to specific regulatory framework, providing protection against foreign takeover and, to some extent, foreign competition. The counterpart is defense industry submission to strict State regulation. Although, at the limit, the structure may contain all nation and allies industrial sectors, the adopted criteria was to consider only the components directly affected by the defense sector decisions in peace times. Industrial facilities as well as qualified engineers, technicians and industrial managers are part of the structure;

b) Defense specific ST\&I, R\&D and T\&E organizations. Includes facilities and qualified scientists, engineers, specialized technicians and program and project managers;

c) Organizations devoted to selecting, recruiting, educating and training combat professionals. Include facilities (military schools of all types and recruiting and training centers) and personnel (instructors, teachers, etc.);

d) Organizations able to manage programs and projects for the development and acquisition of defense products and systems. Requires a professional and stable bureaucracy, with a State career and specific skills to develop this complex activity;

e) Organizations able to manage technological forecasting and technological intelligence, to identify technological threats and promising technological paths to develop new and more effective or efficient defense products and systems.

Concerning dynamics, it seems natural to link a specific process to each of the six PAFLS functional areas described below:

a) Needs determination: definition of requirements for the means needed to implement the operational combat and logistics capabilities suitable for the prioritized scenarios;

b) Defense technological intelligence: identification of technologies with potential to create strategic military capabilities. This function is particularly important because bad choices can have disrupting effects due to budget limitations and the high costs and long time needed to develop complex defense products. The consequence of misjudgments is to create vulnerabilities instead of the desired superiority. Opportunity costs play an important role when selecting alternative technological paths. Identification of technologies owned by foreign countries representing threats is also an important objective; 
c) Defense innovation: basic, applied research and development of new defense products, processes (new tactics based on new and traditional defense products), organizations (new ways to organize administrative and combat institutions) and even market solutions (for instance, new forms of information warfare). Innovation's goal is to field new ways to solve administrative, logistic and operational problems, more effectively and efficiently than the ones known. Technology transfer mechanisms, such as offsets and strategic partnerships for shared development arrangements are also important innovation sources;

d) Manufacturing: to develop and manufacture all sorts of products (weapons, food, drugs, fuels, munitions, clothes, tools, individual protection gear, etc.) and weapons systems required to implement operational combat and logistics capabilities the country needs;

e) Recruitment and skill's development of personnel for operations: there are two kinds of human resources in DL: warriors and logisticians. This functional area will take care only of personnel employed by the State, with direct participation in operations: warriors, and logisticians for operations logistics that belongs to the Armed Forces. It includes voluntary recruitment in peacetime and mandatory mobilization in wartime;

f) Acquisition management: There are two types to consider. One is the management, within factories and research institutes, of the industrial and innovation activities directed to develop and manufacture defense products (supply side). The other, on the demand side, refers to State management of $R \& D$ programs and defense product procurement.

As for the interfaces with the external environment, the following ones deserve mention:

a) With the nation's government as a whole (specially the Minister of Defense), the Armed Forces and the legislative branch, for definition of the defense policy and strategy, the prioritization of military capabilities, formulation and approval of the defense planning and of the defense budgets necessary to implement it; b) With the nation's civilian universities and research institutes, as a source of knowledge for technological intelligence and innovation;

c) With the nation's overall civilian industrial and technological base, since many of the components for defense products come from the civilian market and have dual use;

d) With reliable international partners to guarantee access to foreign sources of technology and components for defense products: since very few countries, if any, can be $100 \%$ autonomous;

e) With national and international suppliers of strategic raw materials for defense (rare earths, uranium, niobium, titanium, etc.);

f) With the DLBLS, for innovation in products, processes and organization and for recruiting and qualification of human resources for supply logistics;

g) With the Armed Forces, to transform combat capabilities operational requirements into defense products and systems specifications.

\subsection{Operations Logistics Subsystem (OLS)}

OLS objective is to provide support for the employment of the Armed Forces in all operations types they might be involved, whether they involve combat, public security, peace keeping or support during natural calamities. To achieve these goals it develops operations, consumer, or "Small l" logistics activities. It is well known and centennial practice by military planners everywhere. OLS main structural components are:

a) The logistic support infrastructure (maintenance facilities, both fixed and mobile, maintenance capital assets, spare parts and maintenance engineers and technicians) required to guarantee defense assets operational availability;

b) The health infrastructure (hospitals, both fixed and mobile, doctors, nurses, medical instruments and medicines) to treat wounded and sick personnel and help prevent illnesses;

c) Transportation means (ships, airplanes, trucks, trains, etc.), infrastructure (ports, airfields, roads, railways, etc.) and skilled professionals required to operate these means and facilities, designed to move people and all kind of materiel between locations; 
d) Materiel handling and storage infrastructure (warehouses, depots, cranes, trained operators, etc.) to handle and store all sorts of materiel (munitions, fuels, spare parts, food, medicine, uniforms, etc.);

e) Lodging infrastructure (bases, quarters, both fixed and mobile, and trained personnel to prepare and serve food, clean uniforms and linen, among many other life supporting functions).

The way these components are organized and managed also varies from country to country. Nevertheless, the most common arrangement is for OLS to be an organic part of the Armed Forces structure. Lately, outsourcing of some of these functions to civilian organizations (enterprises or State organizations) that are not part of AF is also becoming popular in countries involved in conflicts. This is the case, for instance, of the United Kingdom, where the support by private enterprises to operations in Iraq and Afghanistan consumed up to $40 \%$ of the resources spent. (Heidenkamp et al., 2013).

The main functions for the OLS are:

a) Transportation: movement of persons, animals or materials between different places;

b) Supply: of munitions, energy (nuclear materials, petrol, coal or renewable fuels such as alcohol), food, drugs, spare parts, uniforms, etc. These products are obtained through supplier logistics actions and delivered to the combat environment through operations logistics;

c) Maintenance: actions needed to guarantee the operational availability of defense assets. Logistics support is a related term, used to represent maintenance and supply of inputs required by it, such as spare parts and consumables (lubricants, cleaning products, etc.);

d) Healthcare: actions to maintain or recover the health of persons and animals;

e) Lodging and life support: of people and animals;

f) Storage: of all kinds of materiel; and

g) Operations logistic management: the management of all kinds of activities needed to perform operations logistics functions. Civilian logistics experiences and practices can be of great use for military applications, since their objectives are very similar.
As for the interfaces with the external environment, the following ones deserve mention:

a) With PAFLS, to obtain products required by supply actions;

b) With DLBLS, for innovation of products, processes and organization, recruiting and training of human resources and obtainment of assets in peacetime or through mobilization;

c) With the Armed Forces themselves, because many of the activities developed under this heading rely on military personnel that play a double role: warriors and logisticians.

\subsection{Defense Logistics Base Logistics Subsystem (DLBLS)}

DLBLS objective is to create, develop and sustain the DLB. Although conceptually it embraces everything needed for the DLB as a whole, what really justifies its existence as a differentiated entity is the need to build and sustain industrial and innovative capabilities to enable effective and autonomous supplier and operations logistics.

DLBLS requires a professional bureaucracy with stable public service careers and specific skills.

Although, implicitly, the need for this function is accepted and implemented in many countries, to our knowledge it has not yet been treated in the scientific literature as part of a different category of logistics system.

DLBLS main structural components are:

a) Schools and recruiting and training centers devoted to selecting, recruiting, educating and training all types of DL professionals (scientists, engineers, technicians, maintainers, doctors, nurses, economists, management science professionals, etc.). Includes well equipped facilities and needed personnel (administrators, instructors, teachers, support personnel, etc.);

b) Organizations able to conceive, plan and manage public policies and programs for the development and sustainment of the DLB, especially technological innovation and industrial capabilities;

c) Organizations able to perform or manage defense industrial technological intelligence, to prospect for new ways to implement industrial productive processes and also involved with the protection of indigenous strategic technologies for defense; 
d) Organizations able to develop new technologies applicable to all kinds of logistics activities and implement product, process, organizational or marketing innovation to improve effectiveness and efficiency of all DLB functions. Include defense specific R\&D facilities, together with scientists, engineers, specialized technicians and project managers;

e) Organizations able to plan for mobilization of civilian assets and the conversion of industrial and innovative civilian capabilities, to boost defense product innovation and production when required by war;

f) Organizations able to perform commercial intelligence, sales promotion and support to DLB enterprises engaged in sales of defense products to the external market;

Although it is not possible to prescribe institutional and organizational solutions applicable to all situations, the functional areas that DLBLS must perform are universal.

We have identified nine such functional areas:

a) Development and sustainment of defense industrial capability: creation and sustainment of industrial enterprises able to develop applied research and technologies, to innovate, develop, build and maintain defense products. This logistic function depends on other logistics functions, such as: defense product acquisition management (a supplier logistics function), maintenance of defense assets (an operations logistics function), and practically all other DLBLS functions;

b) Development and sustainment of defense innovation capability: creation and sustainment of institutes of science and technology (research institutes) and universities offering high-quality engineering, computer science, basic sciences, undergraduate and graduate courses. The main role of these institutions is to teach and train people, develop applied and pure research, develop technologies and innovate in products, processes and organization with application to defense;

c) Recruitment and skill's development of personnel for logistics: to provide the DLB with qualified logistics professionals able to prosecute all functions pertinent to the three defense logistics categories. The necessary skills cover an ample spectrum. For supplier logistics, the main categories are: engineers, researchers, scientists, information technology professionals, acquisition, development and manufacturing of defense products and systems managers. Operations logistics requires health professionals (doctors, psychologists, dentists, physiotherapist, nurses, etc.), maintenance engineers and technicians, transport, storage, health and maintenance activities managers. Lastly, DLB Logistics, in addition to many of the above mentioned professionals, requires highly qualified managers (engineers, economists, administration science and militaries) able to conceive and implement industrial and innovation policies for defense, and marketing professional to perform commercial intelligence and promotion of external sales of defense products;

d) Mobilization: use of civilian assets for DL. It includes the selective incorporation of assets (ships, planes, vehicles, hospitals, ports, airports, railways, roads, warehouses, reservists, etc.) to the DLB and the Armed Forces. This incorporation requires, in many cases, previous asset preparation to facilitate rapid conversion for defense needs. This may require some investment by the defense sector, but far less than would be necessary if the asset were permanently owned by the State and kept underutilized. Additionally, one has also to consider the possibility of industrial and scientific mobilization to address new problems encountered during conflicts. This includes redirection of activities of companies and other institutions in the civilian sector to participate in war efforts;

e) Commercialization: promotion of the export of defense products as a way to create demand that contributes to sustain the DLB. This function encompasses commercial intelligence, to map foreign markets, and marketing activities to promote sales. Export of defense products is also an effective international relations tool;

f) Financing: defense should depend entirely on the defense budget. Nevertheless, there are some grey areas not covered by it, which are essential for the DLBL and that may require other financing sources. For example, basic education in science, technology, mathematics and engineering, support of defense materiel exports, basic research and technology development in some strategic areas with dual use, sustainment of universities and research centers, acquisition of modern tools and construction of new facilities to foster the development of dual-use industrial capability, etc.; 
g) Industrial technological intelligence: identification of technologies with potential to foster industrial effectiveness, efficiency and competitiveness;

h) Innovation in logistics: basic and applied research and development of new tools, processes, organizations (new ways to organize industrial and logistics processes) and market solutions. Innovation's goal is to field new solutions capable of solving administrative and industrial operational problems. Acquisition of modern tools in the international market, whenever possible, and the use of technology transfer mechanisms are also important sources of industrial innovation;

i) DLBL management: includes the processes for the creation and sustainment of the defense industrial and innovative capability as a whole, (a State responsibility that must be financed by the defense budget), the planning of mobilization, the execution of industrial and commercial intelligence and the promotion of exports.

As for the external environment and its interfaces with the DLBLS, they are practically the same as the existing ones for suppler logistics, although the focus in each case is different. The latter one's goal is provision of means to the Armed Forces, while the first endeavors to develop and sustain the DLB as a whole.

\section{An agenda for future research on defense logistics}

New \& Payne (1995 apud Brick, 2016) pointed to the dilemma between academic rigor and relevance, of research conducted about logistics. In particular, real needs lie in the field of complex and ambiguous problems, unachievable by more restrictive approaches, leading to more interesting questions (from the point of view of impact on management), broad ideas and interdisciplinary research. Näslund (2002) pointed out the need for more qualitative and active research in logistics.

The agenda proposed in this paper consists of four topic groups (Table 1) aiming the strategic management of defense logistics.

\subsection{High level defense planning}

A decision that is a pre-condition for all subsequent government related actions on defense is how much a country should invest to create and sustain its defense instruments.

A proxy for the priority attributed to defense is the percentage of the Gross National Product (GNP) allocated to it. Data from the Stockholm International Peace Research Institute (SIPRI) shows that this figure, in year 2014 , varied from $0.3 \%$ to $11.6 \%$ of the GNP. The world average is higher than $2 \%$. Excessive priority to defense can have disrupting effects on the economy. In the other hand, countries with great wealth or interests to protect and do not invest adequately in defense, may lose their sovereignty, with negative consequences to their economic and social development.

A closely related question is the impact of defense spending on economic growth. Advocates of more defense spending usually use positive impacts as arguments, while their opponents use negative ones. Since the pioneering works of Benoit $(1973,1978)$, many authors have tried to answer this question. See, for instance, Brumm (1997), Dunne et al. (2005), Alptekin \& Levine (2012) and Chen et al. (2014). Nevertheless, so far there is no universally applicable answer. Anyway, according to Smith (2009), macro-economic effects exist only when defense budgets exceed $5 \%$ of the GNP.

Other studies relate defense expenditure and industrial capability and competitiveness building, especially for high and medium high technology products (Mollas-Gallart, 1992; Wang et al., 2012; Winthrop et al., 2002).

Other important decision concerning high level defense planning is how much to invest for the development and sustenance of each of the two defense instruments: the AF and the DLB. There is no single

Table 1. Relevant Defense Logistics (DL) research topics.

\begin{tabular}{|c|c|}
\hline Group & Relevant topics \\
\hline 1. Defense high level planning & $\begin{array}{l}\text { Opportunity costs: defense x other society demands. Defense and economic } \\
\text { development. } \\
\text { Tradeoffs between Defense Logistics Base (DLB) and combat forces. }\end{array}$ \\
\hline 2. Institutions and governance & Responsibility, authority and accountability allocation. \\
\hline 3. Human resources management & $\begin{array}{l}\text { Tradeoffs between conscripts and professional, with integral or partial time } \\
\text { dedication. } \\
\text { Tradeoffs between human resources and automation }\end{array}$ \\
\hline 4. Acquisition management & $\begin{array}{l}\text { How to increase effectiveness and efficiency? } \\
\text { Impact on DLB development and sustainment. }\end{array}$ \\
\hline
\end{tabular}


parameter to represent these priorities. One which is often used as a reasonable approximation is the amount, or the percentage, of the defense budget spent on defense asset development and acquisition from the indigenous DLB. The available figures vary from negligible percentages, for countries that rely entirely on foreign sources, to as much as $50 \%$ of the defense budget for countries that recognize the importance of the DLB as an essential defense instrument.

Weapons purchases from the domestic defense industry and government financing of research and development for defense are essential to provide the necessary financial resources to develop and sustain the DLB.

The above processes, which Tellis et al. (2000) put in the category of "national performance", are not amenable to theoretical studies. Nevertheless, empirical and comparative studies on how various nations tackle these issues would be of great utility.

\subsection{Institutions and governance}

Whatever the priorities given to combat and to industrial and technological capabilities, any defense planning must address the institutional and organizational problem, namely, how to define lines of responsibility, authority and accountability.

There are practically as many arrangements as countries in the international system. Examples appear in Behera (2016), Heidenkamp et al. (2013), Kausal \& Markowski (2000) and Giovachini (2000). Nevertheless, for comparison and research studies, these arrangements may be classified in three generic categories:

a) Arrangements placing both combat and logistics activities under the authority of the Armed Forces (Ex.: Brazil);

b) Arrangements separating these activities and placing them under the authority of distinct institutions. The AF takes care of combat activities and another independent institution (not subordinated to the AF) takes care of defense logistics activities (Ex.: France, Sweden and United Kingdom); and

c) Mixed arrangements (Ex.: United States of America).

Recently, the second category is receiving great acceptance, mainly because it is considered to be more effective (logistics is an activity very different from combat operations and, therefore, also requires processes and professionals very distinct) and efficient (required by the constant increase in the cost of defense products and the concomitant reduction in defense budgets). It is desirable to develop empirical research comparing different nations or dissecting how individual countries handle this problem.

\subsection{Human resources management}

Modern technological war requires specialized skills. Countries with highly educated populations can rely on conscription in times of war to fill this need. Nevertheless, many nations are abolishing universal conscription and this creates the need to attract talented people and train and retain them for defense related activities, as the logistics ones, and not only for combat.

On the other hand, the high cost to maintain large permanent professional Armed Forces leads also to new forms of hiring military personnel (Poutvaara \& Wagener, 2007). One of these is temporary service. This alternative greatly reduces the cost of personnel, because it avoids the burden of maintaining large contingent of retired military for long periods, due to the rise in life expectation. Another tradeoff is between investment in more effective armaments and automation versus large Armed Forces.

\subsection{Acquisition management}

One of the most important of the PAFLS functional areas is undoubtedly acquisition management. Some related issues are which kind of regulatory framework and processes to follow (Tadelis, 2012), which contract type to use (Chu \& Sappington, 2009; Glas et al., 2013) and what kind of skills the program and project managers must have (Williamson et al., 2013).

Other relevant issues for research related to acquisition management are: performance-based logistics and contract management. Availability-based contracts and other similar are also very important. See for instance, Randall et al. (2011), Settanni et al. (2014), Li et al. (2015), Glas et al. (2013), Holmbom et al. (2014) and Caldwell \& Howard (2014).

The development and sustainment of industrial and technological capabilities is also another area of great interest (Mazzucato, 2018; Sabidussi et al., 2014; Xu et al., 2012).

\section{Conclusions}

Defense logistics is an important problem domain, which is essential to any nation's sovereignty and security and involves the spending of huge sums. Therefore it is an extremely relevant subject. Together with the Armed Forces, the Defense Logistics Base is one of the two essential defense instruments. It is also an important tool for development of technological and industrial capabilities that increase the economic competiveness of a country as a whole. Paradoxically, there exist very few published papers about DL. 
This paper covers this subject with a focus on DL strategic management. The resource-based and dynamic capabilities theories cover this subject when dealing with enterprises in the civil market environment. Nevertheless, there is not anything similar applied to defense. There are innumerous as yet unanswered questions relating to industry, technology, human resources, projects, engineering, as well as products, processes, organizational and marketing innovation management in defense.

The conception of effective solutions for problems related to all those questions depends heavily on the existence in a country of a capability to address them from the defense strategic management point of view. Nevertheless, the conceptual and theoretical body of knowledge about this subject, as well as case studies covering different realities, is still insufficiently developed. This paper represents a contribution to fill this gap, by characterizing this problem domain nature and proposing an encompassing conceptual framework for DL. It offers a systemic view that may be very useful to understand DL scope and help to map other more specific views about different aspects related to this problem domain. This broad vision is also essential for future theory formulations, in which new researches may be grounded.

The article also proposes an agenda that consists of four groups of research topics. Although not exhaustive, due to space limitations, the topics are contemporary and deserve the attention of researchers interested in the DL strategic management.

\section{References}

Alptekin, A., \& Levine, P. (2012). Military expenditure and economic growth: a meta-analysis. European Journal of Political Economy, 28(4), 636-650. http://dx.doi. org/10.1016/j.ejpoleco.2012.07.002.

Australia. (2014). Defence capability development handbook 2014. Camberra: Capability Development Group, Department of Defence.

Behera, L. K. (2016). A French solution to India defense acquisition problem. New Dehli: Institude for Defence Studies and Analysis.

Behera, L. K., \& Kaushal, V. (Eds.). (2013). Defense acquisition international best practices. New Delhi: Pentagon Press.

Benoit, E. (1973). Defence and economic growth in developing countries. Boston: Lexington Books.

Benoit, E. (1978). Growth and defence in developing countries. Economic Development and Cultural Change, 26(2), 271-280. http://dx.doi.org/10.1086/451015.

Brasil. (2012a). Livro Branco da Defesa Nacional. Brasília: Ministério da Defesa.
Brasil. (2012b). Estratégia Nacional de Defesa. Brasilia: Ministério da Defesa.

Brick, E. S. (2011). Base Logística de Defesa: conceituação, composição e dinâmica de funcionamento. In Anais do V Encontro Nacional da Associação Brasileira de Estudos de Defesa. Fortaleza: ABED.

Brick, E. S. (2014). As Forças Armadas e a Base Logística de Defesa. Revista Marítima Brasileira, 134, 9-26.

Brick, E. S. (2016). Logística de defesa: uma subárea do conhecimento de importância estratégica para as ciências de gestão. Revista Brasileira de Gestão e Desenvolvimento Regional, 12(2), 301-331.

Brick, E. S. (2017). O sistema de defesa da Suécia. Niterói: Núcleo de Estudos de Defesa, Inovação, Capacitação e Competitividade Industrial, Universidade Federal Fluminense. Retrieved in 2018, March 3, from http:// www.defesa.uff.br/index.php/noticias/18-politica-eestrategia-de-defesa/379-instituicoes-de-defesa-da-suecia

Brick, E. S., Sanches, E. S., \& Gomes, M. G. F. M. (2017). Avaliação de capacidades operacionais de combate: conceituação, taxonomia e práxis. Revista Brasileira de Estudos Estratégicos, 9(17), 11-43.

Brumm, H. (1997). Military spending, government disarray and economic growth: a crosss-country empirical analysis. Journal of Macroeconomics, 19(4), 827-838. http://dx.doi.org/10.1016/S0164-0704(97)00044-X.

Caldwell, N., \& Howard, M. (2014). Contracting for complex performance in markets of few buyers and sellers: the case of military procurement. International Journal of Operations \& Production Management, 34(2), 270294. http://dx.doi.org/10.1108/IJOPM-10-2013-0444.

Chen, P. F., Lee, C. C., \& Chiu, Y. B. (2014). The nexus between defense expenditure and economic growth: new global evidence. Economic Modelling, 36, 474 483. http://dx.doi.org/10.1016/j.econmod.2013.10.019.

Chu, L. Y., \& Sappington, D. E. (2009). Procurement contracts: theory vs. practice. International Journal of Industrial Organization, 27(1), 51-59. http://dx.doi. org/10.1016/j.ijindorg.2008.04.001.

Davies, P. K. (2002). Analytic architecture for capabilities-based planning, mission-system analysis, and transformation. Santa Monica: Rand Corporation.

Defee, C. C., Williams, B., \& Randall, W. S. (2010). An inventory of theory in logistics and SCM research. International Journal of Logistics Management, 21(3), 404-489. http://dx.doi.org/10.1108/09574091011089817.

Dunne, J., Smith, R., \& Willenbockel, D. (2005). Models of military expenditure and growth: a critical view. Defence and Peace Economics, 16(6), 449-461. http:// dx.doi.org/10.1080/10242690500167791.

Eccles, H. (1965). Military concepts and philosophy. New Brunswick: Rutgers University Press. 
Ekstrom, T., Dorn, M., \& Skoglund, P. (2015). Swedish defence acquisition transformation: a Research Agenda. In Proceedings of the Twelfty Annual Acquisition Research Symposium (Vol. 1, pp. 28). Monterey: US Naval Postgraduate School.

Ellram, L. M. (1993). A framework for total cost of ownership. International Journal of Logistics Management, 4(2), 49-60. http://dx.doi.org/10.1108/09574099310804984.

Gammelgaard, B. (2004). Schools in logistics research? A methodological framework for analysis of the discipline. International Journal of Physical Distribution \& Logistics, 34(6), 479-491. http://dx.doi. org/10.1108/09600030410548541.

Giovachini, L. (2000). L'armement français au XXe siècle: une politique à L'épreuve de l'histoire. Paris: Ellipses Édition Marketing S.A.

Glas, A., Hofmann, E., \& Eßig, M. (2013). Performancebased logistics: a portfolio for contracting military supply. International Journal of Physical Distribution \& Logistics Management, 43(2), 97-115. http://dx.doi. org/10.1108/IJPDLM-12-2011-0229.

Great Britain. Minister of Defence. (2014). How defence works. London: Ministry of Defence.

Gropman, A. (Ed.). (1997). The Big L: american logistics in World War II. Washington: National Defense University Press. http://dx.doi.org/10.21236/ADA421840.

Heidenkamp, H., Louth, J., \& Taylor, T. (2013). The Defence Industrial Triptych: the government as customer, sponsor and regulator. Abingdon: Taylor\&Francis.

Holmbom, M., Bergquist, B., \& Vanhatalo, E. (2014). Performance-based logistics: an illusive panacea or a concept for the future? Journal of Manufacturing Technology Management, 25(7), 958-979. http://dx.doi. org/10.1108/JMTM-06-2012-0068.

Kausal, B. A., \& Markowski, S. (2000). A comparison of the defense acquisition systems of Australia, Japan, South Korea, Singapore and the United States. Fort Belvoir: Defense Systems Management College Press. http://dx.doi.org/10.21236/ADA381900.

Li, Z., Ryan, J. K., \& Sun, D. (2015). Multi-attribute procurement contracts. International Journal of Production Economics, 159, 137-146. http://dx.doi. org/10.1016/j.ijpe.2014.09.032.

Markowski, S., Hall, P., \& Wylie, R. (Eds.). (2010). Defence procurement and Industry Policy: a small country perspective. (Vol. 11). Abingdon: Routledge.

Masson, H., Brick, E. S., \& Martin, K. (2015). Production d'armement: le Brésil en quête d'autonomie. Paris: Fondation pour la Recherche Stratégique.

Mazzucato, M. (2018). Mission-Oriented Research \& Innovation in the European Union: a problem-solving approach to fuel innovation-led growth. Brussels: European Comission.
Melo, R. (2015). Indústria de defesa e desenvolvimento estratégico. Brasília: FUNAG.

Mollas-Gallart, J. (1992). Military production and innovation in Spain. London: Harwood.

Mowery, D. C. (2012). Defense-related R\&D as a model for "Grand Challenges" technology policies. Research Policy, 41(10), 1703-1715. http://dx.doi.org/10.1016/j. respol.2012.03.027.

Näslund, D. (2002). Logistics needs qualitative research: especially action research. International Journal of Physical Distribution \& Logistics Management, 32(5), 321-338. http://dx.doi.org/10.1108/09600030210434143.

New, S. J., \& Payne, P. (1995). Research frameworks in logistics three models, seven dinners and a survey. International Journal of Physical Distribution \& Logistics Management, 25(10), 60-77. http://dx.doi. org/10.1108/09600039510147663.

O'Hanlon, M. E. (2009). The Science of War: defense budgeting, military technology, logistics and combat outcomes. Princeton: Princeton University Press. http:// dx.doi.org/10.1515/9781400830930.

Olavarrieta, S., \& Ellinger, A. (1997). Resource-based theory and strategic logistics research. International Journal of Physical Distribution \& Logistics Management, 27(9-10), 559-587. http://dx.doi.org/10.1108/09600039710188594.

Penrose, E. T. (1959). The theory of the growth of the firm. New York: John Wiley \& Sons.

Peppers, J. J. (1988). History of the United States military logistics, 1935-1985. Huntsville: Logistics Education Foundation Publishing.

Polanyi, M. (2009). With a new foreword by Amartya Sen. In M. Polanyi, The tacit dimension. Chicago: The University of Chicago Press.

Poutvaara, P., \& Wagener, A. (2007). To draft or not to draft? Inefficiency, generational incidence, and political economy of military conscription. European Journal of Political Economy, 23(4), 975-987. http://dx.doi. org/10.1016/j.ejpoleco.2006.12.001.

Randall, W. S., Nowicki, D. R., \& Hawkins, T. G. (2011). Explaining the effectiveness of performance-based logistics: a quantitative examination. International Journal of Logistics Management, 22(3), 324-348. http://dx.doi.org/10.1108/09574091111181354.

Sabidussi, A., Lokshin, B., de Leeuw, T., Duysters, G., Bremmers, H., \& Omta, O. (2014). A comparative perspective on external technology sourcing modalities: the role of synergies. Journal of Engineering and Technology Management, 33, 18-31. http://dx.doi. org/10.1016/j.jengtecman.2014.02.001.

Settanni, E., Newnes, L., Thenent, N. E., Parry, G., \& Goh, Y. M. (2014). A through-life costing methodology for use in product-service-systems. International Journal of Production Economics, 153, 161-177. http://dx.doi. org/10.1016/j.ijpe.2014.02.016. 
Smith, R. (2009). Military economics: the interaction of power and money. Hampshire: Palgrave Macmillan.

Sutherland, J. (1975). Systems analysis administration and architecture. New York: Van Nostrand Reinhold and Company.

Sweden. Swedish Armed Forces. (2014). Military strategic planning. Stockholm: Ministry of Defence.

Tadelis, S. (2012). Public procurement design: lessons from the private sector. International Journal of Industrial Organization, 30(3), 297-302. http://dx.doi.org/10.1016/j. ijindorg.2012.02.002.

Taylor, B. (2013). TTCP technical report: analysis support to strategic planning. Otawa: The Technical Cooperation Programm.

Teece, D. (2009). Dynamic capabilities \& strategic management: organizing for innovation and growth. Oxford: Oxford University Press.

Teece, D. J., Pisano, G., \& Shuen, A. (1997). Dynamic capabilities and strategic management. Strategic Management Journal, 18(7), 509-533. http://dx.doi. org/10.1002/(SICI)1097-0266(199708)18:7<509::AIDSMJ882>3.0.CO;2-Z.

Tellis, A., Bially, J., Mcpherson, M., \& Sollinger, J. (2000). Measuring national power in the postindustrial age. Santa Monica: Rand Corporation.

The Technical Cooperation Program - TTCP. (2006). Guide to capability-based planning. Retrieved in 2015, August 21, from http://www.acq.osd.mil/ttcp/reference/index. html\#tech_docs

Thorpe, G. (1996). Pure Logistics: the science of war preparation (3rd ed.). Washington: National Defense University Press.

United States. Department of Defense. (2011) Joint logistics Lexicon. Washington: Joint Chiefs of Staff.
United States. Department of Defense. (2017). DOD instruction 5000.02: operation of the defense acquisition system. Washington: Department of Defense.

Waeyenbergh, G., \& Pintelon, L. (2002). A framework for maintenance concept development. International Journal of Production Economics, 77(3), 299-313. http://dx.doi.org/10.1016/S0925-5273(01)00156-6.

Waeyenbergh, G., \& Pintelon, L. (2009). CIBOCOF: a framework for industrial maintenance concept development. International Journal of Production Economics, 121(2), 633-640. http://dx.doi.org/10.1016/j. ijpe.2006.10.012.

Wang, T., Shyu, S., \& Chou, H. (2012). The impact of defense expenditures on economic productivity in OECD countries. Economic Modelling, 29(6), 21042114. http://dx.doi.org/10.1016/j.econmod.2012.06.041.

Williamson, J. M., Lounsbury, J. W., \& Han, L. D. (2013). Key personality traits of engineers for innovation and technology development. Journal of Engineering and Technology Management, 30(2), 157-168. http://dx.doi. org/10.1016/j.jengtecman.2013.01.003.

Winthrop, M. F., Deckro, R. F., \& Kloeber, J. M., Jr. (2002). Government R\&D expenditures and US technology advancement in the aerospace industry: a case study. Journal of Engineering and Technology Management, 19(3-4), 287-305. http://dx.doi.org/10.1016/S09234748(02)00022-X.

Xu, K., Huang, K.-F., \& Gao, S. (2012). Technology sourcing, appropriability regimes, and new product development. Journal of Engineering and Technology Management, 29(2), 265-280. http://dx.doi.org/10.1016/j. jengtecman.2012.03.003.

Yoho, K., Rietjens, S., \& Tatham, P. (2013). Defence logistics: an important research field in need of researchers. International Journal of Physical Distribution \& Logistics, 43(2), 80-96. http://dx.doi.org/10.1108/ IJPDLM-03-2012-0079. 